\title{
Sve se promijenilo
}

Ovo je četvrti redoviti broj časopisa Sociologija i prostor u 2021. godini. Kao i prvi poseban broj (Vol. 59 No. 219) početkom ove godine i ovaj zadnji je dominantno posvećen suvremenim i aktualnim društvenim izazovima vezanim za dvogodišnju globalnu pandemijsku situaciju u lokalnom hrvatskom ozračju.

Radovi su rezultat znanstvene konferencije pod nazivom „Post-pandemijski svijet - loša slika ili dobra prilika" (The post-pandemic world - A bad picture or a good opportunity) koja je održana u Zagrebu, 19. i 20. ožujka 2021. godine, u organizaciji Communication Management Forum-a 2021. godine. Konferenciju su organizirale tri znanstvene/ visokoobrazovne ustanove: Edward Bernays University College, Institut za društvena istraživanja u Zagrebu i Institut za turizam. Radovi objavljeni u ovom broju nastali su na temelju izlaganja na konferenciji i obuhvaćaju širok krug tema vezanih za globalnu pandemiju i hrvatski kontekst. U globalnom okviru svjetske pandemije, radovi daju odgovore na neke od ključnih izazova funkcioniranja društva i ukazuju na nastajanje novih modela i strategija suočavanja u kriznim uvjetima, koji nadoknađuju ustaljene načine djelovanja u prethodnim razdobljima.

Kao što autori i autorice u svojim tekstovima detaljno prikazuju i problematiziraju, u ovom trenutku „sve se promijenilo“. Osobna i grupna (poslovna) komunikacija preseljene su dobrim dijelom iz stvarnog u digitalni svijet, čime su zahvaćene gotovo sve kategorije stanovništva... Apostrofirana je važnost kriznog komuniciranja u različitim aspektima kojim su obuhvaćena sva ključna društvena područja i njihovi akteri... Novi komunikacijski modeli i prakse proželi su sve aspekte našeg intimnog i društvenog života... Iz stvarnog u virtualni prostor prebačeni su poslovni sastanci i putovanja, rođendani i vjenčanja... U kulturi dominiraju digitalne forme, on-line kazališne predstave, muzejske izložbe, filmski festivali... Analizirani su i neki rijetko istraživani društveni fenomeni u pandemijskim okolnostima, kao što su promjene u medijima, kriminalitet, položaj umirovljenika... A o obrazovanju na daljinu mnogo se piše, ali to je, prema našem mišljenju, tek početak.

U suradnji s autorima, recenzenti su doprinijeli da se u pandemijskim okolnostima postigne maksimum kvalitete tekstova s ciljem objavljivanja široke palete tema. I u tome su zajednički uspjeli. Naš stav je da će objavljeni radovi jednoga dana, kada pandemija prođe, biti dragocjena svjedočanstva jednog zaista rijetkog društvenog fenomena i vremena u kojem je trajao. Istovremeno, bit će, na temelju mogućnosti znanstvenih predviđanja u različitim raznorodnim područjima, dragocjeni doprinos društvenom snalaženju u budućim potencijalno sličnim situacijama.

I na kraju, da se osvrnemo na naslov konferencije: Post-pandemijski svijet - loša slika ili dobra prilika. Odgovor bi možda trebao glasiti - i jedno i drugo, gledano i globalno i lokalno. A svaka „loša slika“ može biti polazište za novu „dobru priliku“, utemeljenu 
na novim spoznajama, praksama, iskustvima, pa i vrijednostima. Na taj način pandemija je pokazala da je, kako to kaže profesor Vjeran Katunarić, „svijet ipak cjelina, a ne nakupina zvjezdane prašine“ (Glas Slavonije, 15. siječnja 2022.).

Ankica Marinović

Lana Peternel 